\title{
Consequences of Beaver, Castor canadensis, Flooding on a Small Shore Fen in Southwestern Quebec
}

\author{
Joyce M. Reddoch and Allan H. RedDOCH \\ 548 Rivershore Crescent, Gloucester, Ontario K1J 7Y7 Canada
}

Reddoch, Joyce M., and Allan H. Reddoch. 2005. Consequences of Beaver, Castor canadensis, flooding on a small shore fen in southwestern Quebec. Canadian Field-Naturalist 119(3): 385-394.

We describe the changes in a small peatland in Gatineau Park, Quebec, between 1878 and 2004. We correlate these changes with water levels and Beaver activity during this period. A shore fen persisted until 1980 under a regime of relatively stable water levels interspersed with episodes of somewhat higher water that killed encroaching trees. Significantly higher water levels in the early 1980s transformed the fen into a shallow water wetland containing a few partially-floating fragments of the fen. In 2003 a beaver dam collapse lowered the water level dramatically, exposing the peat surface and making it available for colonization by existing aquatic and shoreline communities. If maintaining the fen had been part of the Park's beaver control program, water levels should have been allowed to fluctuate in order to control tree growth but not permitted to rise high enough or for long enough to drown the fen.

Key Words: Beaver, Castor canadensis, fen, flooding, floristics, shallow water wetland, shore fen, wetland succession, water levels, Quebec.

The Precambrian uplands of eastern Ontario and western Quebec adjacent to the Ottawa River valley are dotted with many small lakes, a number of which support fens along their shores. Although botanical exploration of the Ottawa area began in the 1860s, there appear to be few published floristic or ecological studies of these fens. A start on describing the calcareous fens within $50 \mathrm{~km}$ of the Parliament Buildings in Ottawa was made in the late 1970s (Reddoch 1979, 1984, 1989; Reddoch and Reddoch 1997).

By the end of the 1920s Beaver populations in eastern Canada and elsewhere had declined to low levels because of excessive exploitation. Thereafter, populations began to rise again, partly the result of quotas, trap line restrictions and reintroductions of breeding animals (Banfield 1974; Peterson 1966) and partly because some human activities created new Beaver habitat (Ingle-Sidorowicz 1982). In Quebec, trapping was banned altogether between 1931 and 1941, and among the places where breeding pairs were introduced was Gatineau Park, across the Ottawa River from Ottawa, Ontario. By the end of the 1950s, Beavers were widespread and abundant in the park and adjacent areas, as was evident from the many new Beaver dams and subsequent flooding of low-lying areas. By the late 1970s, a program to control water levels in Beaver ponds was initiated in Gatineau Park in order to ensure public safety and protect man-made structures (National Capital Commission 2004*). Since then, there have been ten aerial surveys to locate and census the population. The most recent survey, in $2002-2003$, found 283 active colonies, an average of 0.78 colonies per square kilometre (I. Beaudoin-Roy, personal communication). In Gatineau Park, Beavers are present in an area for a year or more and then are absent for another period of time. They seem to move about more during times of high precipitation (M. Leclair, private contractor, personal communication). In northeastern North America, Beavers frequently inhabit peatlands, especially where there is open water. Their flood waters can modify or kill the vegetation on grounded parts of peatlands while having varying effects on those parts of the peatland that are floating (Damman and French 1987; Mitchell and Niering 1993; Muir-Hotaling c. 2001*; Rebertus 1986; Schwintzer and Williams 1974; personal observation).

We have been doing botanical work in Gatineau Park since the late 1960 s, concentrating especially on longterm studies of some native orchid colonies (Reddoch and Reddoch 1997). In the spring of 2003 we noticed that the water level of Black Lake suddenly had dropped a metre, exposing an expanse of peat in the southeastern corner of the lake where we had observed a fen in the 1960s and 1970s. We report here the changes in the wetland that we have recorded on a sporadic basis between 1967 and 2004. From literature references, herbarium collections, air photographs and wood samples, we deduce the various stages of this wetland since 1878 , a total of 127 years. We correlate these observations with the water levels and Beaver activity during this period and consider what management strategies would have been necessary to preserve the fen habitat.

\section{Study Site}

The study site is about $15 \mathrm{~km}$ west-northwest of the Parliament Buildings in Ottawa, Ontario, at the edge of Black Lake $\left(45^{\circ} 29^{\prime} 29^{\prime \prime} \mathrm{N}, 7^{\circ} 51^{\prime} 46^{\prime \prime} \mathrm{W}\right)$ in Gatineau Park. The park, which is in the Quebec portion of the National Capital Region, is $363 \mathrm{~km}^{2}$ in 
area; it is owned and managed by the National Capital Commission.

The climate of the region is continental, with warm, moist summers and cold, snowy winters. The mean daily maximum and minimum July temperatures at Ottawa are $26.5^{\circ} \mathrm{C}$ and $15.4^{\circ} \mathrm{C}$, while the corresponding January temperatures are $-6.1^{\circ} \mathrm{C}$ and $-15.3^{\circ} \mathrm{C}$. Mean annual precipitation is $943 \mathrm{~mm}$, of which one quarter falls as snow. Mean precipitation for the month of July is $90.6 \mathrm{~mm}$; the mean frost-free period is 159 days, extending from the beginning of May to early October (Environment Canada 2004*). At Black Lake, $300 \mathrm{~m}$ above mean sea level and about $200 \mathrm{~m}$ higher than Ottawa, the temperatures are slightly cooler, the precipitation is slightly higher and the mean frostfree period is slightly shorter (Crowe 1984; Environment Canada 2004*).

Black Lake is on King Mountain, part of the Eardley Escarpment that defines the southwestern exposure of the Canadian Shield in this area. The lake is situated in an east-west trough along a fault line between two ridges rising 50-60 m above it. The bedrock is Precambrian diopsidic gneiss interspersed with granite pegmatite (Hogarth 1962, 1970); it is exposed or shallowly covered with glacial till. The lake is surrounded by forests more than 80 years old that are characteristic of the Middle Ottawa Section of the Great Lakes - St. Lawrence Forest Region of which they are a part (Lopoukhine 1974; Rowe 1972). Much of what is now Gatineau Park was logged and subsequently burned over in the 1800s and early 1900s (Mott and Farley-Gill 1981). The north-facing slope to the south, and adjacent eastern slope, are covered predominantly with Eastern Hemlock (Tsuga canadensis (L). Carrière) accompanied by a few scattered individuals of Eastern White Pine (Pinus strobus L.), Eastern White Cedar (Thuja occidentalis L.), Yellow Birch (Betula alleghaniensis Britton),White Birch (B. papyrifera Marshall) and Red Maple (Acer rubrum L.), while the forest on the southfacing slope farther away to the north is mainly deciduous with Sugar Maple (Acer saccharum Marshall) and Red Oak (Quercus rubra L.) co-dominant.

Black Lake is about 2 ha in area; it is $150 \mathrm{~m}$ across and has a maximum depth of about $8 \mathrm{~m}$. Much of the shoreline is bedrock. Measurements made at the 2-m depth in the lake on 19 July 1982 (Éco-recherches Inc. $1983^{*}$ ) were as follows: water temperature $21.5^{\circ} \mathrm{C}$, $\mathrm{pH}$ 7.1, dissolved oxygen $7.9 \mathrm{ppm}$, carbon dioxide $6 \mathrm{mg} / \mathrm{L}$, alkalinity $10 \mathrm{mg} / \mathrm{L}$, total phosphates $0.04 \mathrm{mg} / \mathrm{L}$ and sulphates $14 \mathrm{mg} / \mathrm{L}$. The only sources of water are rainfall and runoff from the surrounding slopes, which constitutes a catchment area of about 8 ha. The outlet, and consequently the location of the Beaver dam that affects water levels, is in the southwestern corner of the lake. The subject wetland, 0.12 ha in area, is situated in the southeastern corner, adjacent to the north-facing, $50^{\circ}$ slope (Figure 1). This slope provides a cool microclimate for the wetland by shading it for much of the year, except in the summer. The ice forms first in this part of the lake in the fall and thaws last here in the spring.

\section{Materials and Methods}

Air photos were examined at the National Air Photo Library in Ottawa. Useful images were available for 1925, 1928, 1935, 1938, 1944, 1948, 1951, 1966, 1971, 1988, 1994, 1999, 2001 and 2002. Some photos were not useful because they were taken in the spring, winter or autumn when the sun was low and the north-facing slope cast a heavy shadow that obliterated details of the wetland and the outlet stream. Scales ranged from 1:6000 to $1: 16000$.

Our field notes, as well as our photographs taken at various times between 1967 and the present, provided considerable information. Field work in 2003 and 2004 consisted of identifying the flora on the newly exposed expanse of peat and mapping the area with a 100' steel tape and compass. Inaccessible parts of the site were examined with binoculars. Water levels were estimated from the shapes of the lake in the air photos and, in the field, from the positions of the water in relation to the high-water mark on the steep bedrock face adjacent to the wetland.

Information about the historical tree inventory of the fen was obtained from old stumps and fallen logs by wood identification techniques (Hoadley 1990; Panshin and de Zeeuw 1980). Twenty-six wood samples, a few centimetres in size, were collected and determined to genus level or better. The effects of water immersion and decay caused some difficulties in the identifications. Another difficulty arose with Thuja occidentalis samples because these trees were the stunted form found in fens that are not considered in most commercial timber identification work. This form is represented by a dead $T$. occidentalis tree we had collected in another Ottawa area fen (Reddoch 1984). When it died, it was 43 years old, $1 \mathrm{~m}$ tall and $3 \mathrm{~cm}$ in maximum diameter. It was identified partly by its remnants of fibrous inner bark. Like some samples from Black Lake, its wood was hard with annual rings as narrow as $0.1 \mathrm{~mm}$. In contrast, a sample of $T$. occidentalis from a stump on the shoreline of Black Lake near the wetland was quite normal with annual rings about $4 \mathrm{~mm}$ wide. It was also difficult to distinguish Betula from Alnus because the set of diagnostic characters sometimes gave conflicting results, likely the consequence of a nutrient-poor habitat. However, in the case of stumps and trunks more than $20 \mathrm{~cm}$ in diameter, Alnus can be excluded. In some cases Betula papyrifera was readily identified by remnants of bark.

Vascular plants collected during this study have been deposited in the herbaria of the Canadian Museum of Nature (CAN) and Agriculture Canada (DAO) in Ottawa. Grasses were identified by S. J. Darbyshire at DAO in accordance with Dore and McNeill (1980). Mosses collected in 1978 were identified by R. R. Ireland and deposited in Canadian Museum of Nature Moss collection (CANM). Vascular plant (except grass- 


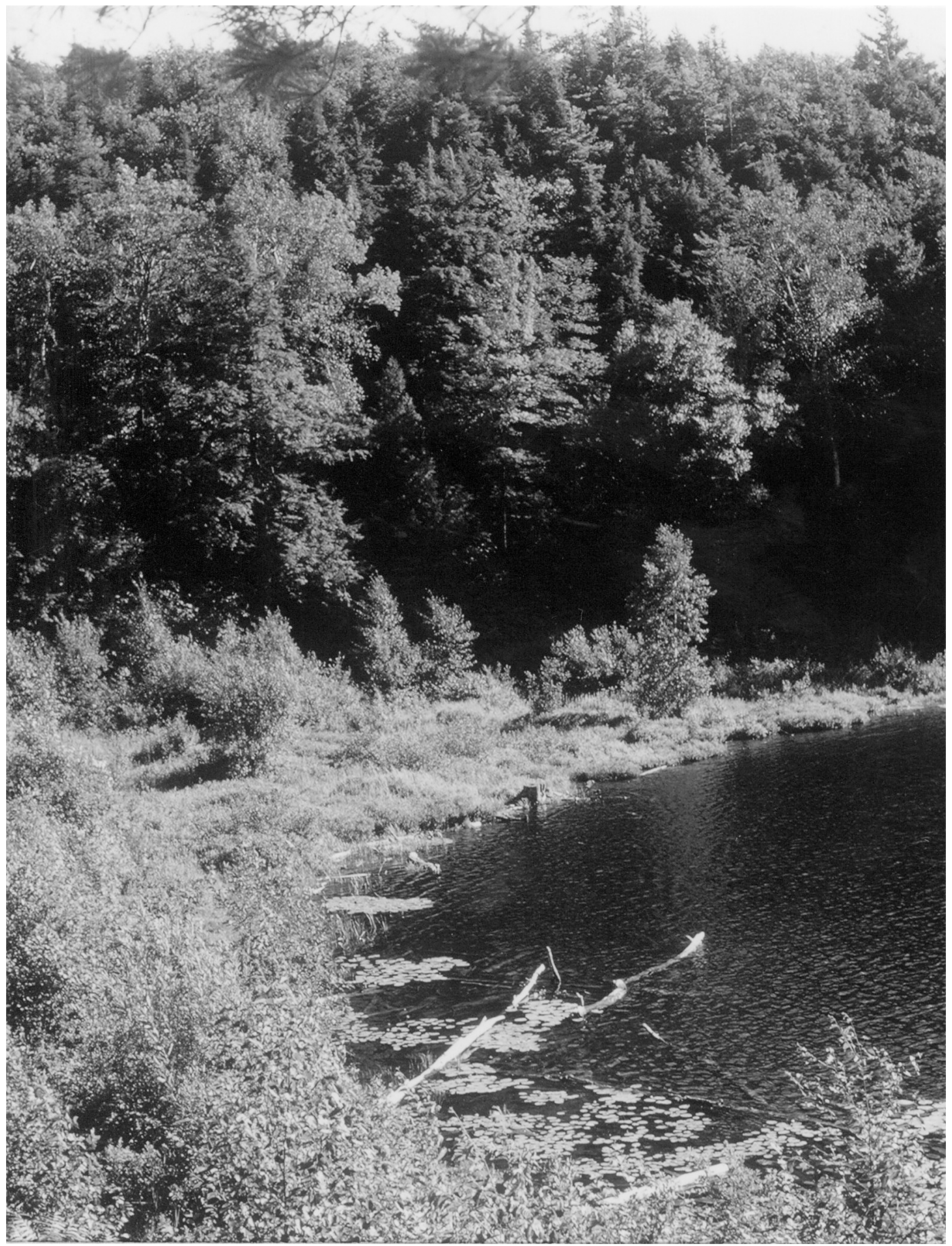

FIGURE 1. The shore fen at Black Lake as viewed from the slope to the north on 27 July 1971. Photograph by Joyce M. Reddoch. 
es) and bryophyte nomenclature follow Newmaster et al. (1998). The principal depositories for local collections, CAN and DAO, were searched for possible previous Black Lake collections by looking for species that are characteristic of peatlands in this area. No additional species were found. The McGill University Herbarium (MTMG) was examined for Ottawa District orchid collections.

Where possible, the terminology used for wetlands is from The Canadian Wetland Classification System (National Wetlands Working Group 1997) and Crum (1988). In particular, shallow water wetlands have "free surface water up to $2 \mathrm{~m}$ deep, present for all or most of the year, with less than $25 \%$ of the surface water area occluded by standing emergent or woody plants. Submerged or floating aquatic plants usually dominate the vegetation" (National Wetlands Working Group 1997). Fens are "grass-, sedge-, or reed-dominated peatland[s], often with some shrub growth or a scant tree cover, developed under the influence of mineral-rich, aerated water at or near the surface. ..." (Crum 1988).

\section{Results}

1878-1889. On 8 July 1878, James Fletcher collected Pogonia ophioglossoides (DAO 767100) and Platanthera clavellata (Michx.) Luer (DAO 267278, MTMG 47571; sub Habenaria tridentata Hook.) in what he described in his Flora Ottawaensis (Fletcher 1893) as "a tiny bog at Black Lake, high on King's [sic] Mountain, Chelsea, P.Q." In earlier parts of the same publication (Fletcher 1889a, 1889b) he listed Solidago uliginosa Nutt. from a "swamp on King's [sic] Mountain" and Utricularia cornuta Michx. from "a small swamp at Black Lake Kingsmere". (In his writings and on herbarium labels Fletcher used "swamp" and "bog" interchangeably. Chelsea [now called Old Chelsea] and Kingsmere were nearby hamlets at this time.) It is likely that all four species were recorded from the same locality; these species taken together suggest an open fen habitat.

1925-1938. The air photos taken in 1925 and 1928 show Black Lake surrounded by forest that extended to the water's edge. By contrast, water levels in 1935 and 1938 had risen somewhat and the trees along the northern and northeastern shores were no longer present. A number of fallen trunks were visible in the water where the trees had previously been. (In 2003 the stumps of these trees were once again exposed. All of the trees we sampled were Betula papyrifera.). In the southeastern corner of the lake, the triangular area of the wetland was covered with moderately spaced, moderate-size trees, mostly deciduous, except for a wide band along the lake edge that appears to be open fen. The width of the band was calculated from the 1928 air photo to be about $3 \mathrm{~m}$.

1938-1951. From 1938 to 1944 the lake level appears to have dropped somewhat. However, in 1948 the shape of the lake indicates a somewhat higher water level and there appears to be a band of water between the wetland surface and the shore. By 1951 the band had disappeared but the water was still relatively high. Trees were no longer evident in the wetland, but the fen mat remained. There was now a distinct treeless shoreline around the rest of the lake about $10 \mathrm{~m}$ wide showing that sometime during this period water levels had been even higher.

1966-1978. In the late 1950s a scenic parkway was built across the northern slope within $50 \mathrm{~m}$ of Black Lake. Its embankment encroaches slightly on a small section of the high-water north shore. Its design seems to have allowed for natural drainage into the lake, and any impact on the lake, other than visual, is not evident. The parkway is closed in the winter. The air photos of 1966 and 1971 indicate that the lake had returned to the low levels of the 1920s. A 1966 air photo is the first one to show evidence of Beavers: a lodge in the northwest corner of the lake. Aiken and Gillett (1974) reported the presence of a Beaver dam in 1971. We visited and photographed the fen from time to time during this period and in 1978 made a species list and collected a few specimens. [See Reddoch and Reddoch (1987) for a photograph of the fen in 1978.] The wetland consisted of an open, poor fen mat edged along the lake with a semi-floating shrub margin. The poor fen mat (Sphagnum lawn) was dominated by Sphagnum magellanicum and supported Thelypteris palustris, Pogonia ophioglossoides, Drosera rotundifolia and Triadenum virginicum. Some plants of Carex cryptolepis Mack., Carex sp., Juncus brevicaudatus, Iris versicolor, Cicuta bulbifera, Lycopus uniflorus, Aster puniceus L., Bidens sp., Euthamia graminifolia and Solidago sp. were also present. There were scattered shrubs of Chamaedaphne calyculata, as well as some saplings of Alnus incana ssp. rugosa and young trees of Betula papyrifera that had grown to a height of $4 \mathrm{~m}$ by 1978 . A few plants of Calla palustris L. grew in water-filled depressions in the mat. A mid-summer paper $\mathrm{pH}$ reading of the surface fen water in 1977 was 5.5 The semifloating mat at the lake/fen interface (shrub fringe) consisted mainly of Chamaedaphne calyculata, which was accompanied by the mosses Sphagnum magellanicum, S. teres, Calliergon stramineum (Brid.) Kindb. and Campylium polygamum (Schimp. in B.S.G.) C. Jens. The shape of the fen/lake interface was essentially unchanged from that of 1925 . There was a narrow aquatic vegetation zone around most of the lake shore but not in front of the fen, presumably because the water was too deep there. Nuphar variegata was visually the dominant species. (In 1971 Aiken and Gillett (1974) identified 19 species of aquatic vascular plants around the lake.) In the late 1960s and early 1970s, there were a few plants of the orchid Platanthera clavellata, which had been collected by Fletcher in 1878 , on the lake shore to the north of the fen, but we did not find any plants in the fen. In 1978 we noticed that the fen had become somewhat wetter than previ- 
ously and a stash of deciduous branches along the lake edge of the fen was evidence of Beaver activity.

1983-2002. In 1983 the Sphagnum lawn had been replaced by open water dotted with the still-standing dead Betula papyrifera trees. Much of the Chamaedaphne calyculata shrub fringe and adjacent Sphagnum lawn remained intact as a semi-floating band 2-3 m wide, although many of the shrubs were dying. A large Beaver lodge was prominent in the shrub fringe. The water level in 1983 was at least $30 \mathrm{~cm}$ above that of 1978 , and by 1988 was a metre higher than in the 1970s. An aquatic community similar to that around the rest of the lake and consisting most prominently of Nuphar variegata, Sparganium americanum and Carex sp. became established in the area of the former grounded Sphagnum lawn. By 1990 only stubs remained of the $B$. papyrifera trees; the trunks likely had provided building materials for the two additional Beaver lodges that had appeared by that time. The emergent parts of some larger fallen trunks provided sunning places for Painted Turtles (Chrysemys picta) and Northern Leopard Frogs (Rana pipiens). In 1992 we photographed a Blanding's Turtle (Emydoidea blandingi) there, a species that is extremely rare $(\mathrm{S} 1)$ in Quebec (Société de la faune et des parcs $\left.2004^{*}\right)$.

With continuing higher water, the former Chamaedaphne fringe became a line of low-lying islands, which can be seen in air photos as an irregular necklace along the line of the former fen margin and at the edge of the underlying peat. Over the years, the islands slowly have continued to fragment and disintegrate. The fragments have moved shoreward away from their original locations, likely the result of buffeting by wave and ice action driven by the prevailing westerly winds. The dominant vegetation on the islands changed from Chamaedaphne calyculata to Carex lasiocarpa, although the former was still well-represented. In 2002, July and August were hotter than normal and among the driest on record (Environment Canada 2004*). As a result, the water level of the lake dropped about $0.75 \mathrm{~m}$ and three islands that were close to the shores, one at the north end and two at the south end, were left beached.

The northern island measured $0.9 \mathrm{~m} \times 1.30 \mathrm{~m}$; the depth of the peat base as it sat compressed by its own weight was about $30 \mathrm{~cm}$. All of the species included in the 1978 description of the Sphagnum lawn (above) were present, except for Cicuta bulbifera, Aster puniceus, the Solidago species and Betula papyrifera. There was, in addition, one plant each of five other species: Typha latifolia, Carex pseudo-cyperus, Viola macloskeyi ssp. pallens, Lysimachia thyrsifolia and Eupatorium perfoliatum. Alnus incana was represented by one seedling $15 \mathrm{~cm}$ high. The dominant moss, Sphagnum magellanicum, was accompanied by S. teres and Campylium sp. [See Appendix for complete species list. A close-up photograph of this island with some of its eight flowering stems of Pogonia ophioglossoides is shown in St. George (2002).] By contrast, the two peat islands that were stranded on the south shore had a limited number of species, the dominant cover being Carex sp., accompanied by a few plants of Thelypteris palustris and Chamaedaphne calyculata, as well as some Sphagnum teres. The dimensions of these two islands were $1.7 \mathrm{~m} \times 2.2 \mathrm{~m}$ and $0.85 \mathrm{~m} \times 0.40 \mathrm{~m}$. These three islands at the northern and southern limits of the island chain represent the extremes in the gradient of the plant compositions of the islands. The farther north the islands were situated, the more species they supported.

2003-2004. In late May of 2003, the lake was at its highest level, as was usual after snow melt. Two weeks later the water level had dropped about a metre because the Beaver dam had given way. Great volumes of water had cascaded down the escarpment onto the lowlands $200 \mathrm{~m}$ below (M. Leclair, personal communication). Because there were no Beavers in the lake in 2002, the dam had not been kept in good repair. A device had been installed in the dam that year to maintain a relatively constant water level (M. Leclair, personal communication) but apparently was not functioning adequately in the spring of 2003.

As a result of the drop in water level, the remaining islands settled down onto the peat substrate of the former fen. One fragment about a metre square was stranded on top of a large, previously submerged stump and a smaller piece came to rest on a fallen tree trunk. The substrate was relatively homogeneous, unconsolidated peat, with a shallow surface gradient upward from the lake. Throughout the summer the peat remained saturated. The central area was covered with shallow pools, while the inland borders were moist. Overall there was a related gradient of gradually decreasing moisture from the lake edge to the inland shore of the former wetland. The peat surface was dotted with stubs and stumps rooted in the peat and corresponding-sized trunks lying on and in the peat. There were many Betula papyrifera stubs of $6-10 \mathrm{~cm}$ diameter, as well as a few Alnus incana stubs of similar size. Their presence is consistent with our 1978 observations. Also revealed were a number of B. papyrifera stumps in the range of 30-45 cm basal diameter and fallen trunks of related diameters, some still retaining their bark. In addition there were a few similarly sized stumps of Pinus strobus and Thuja occidentalis, and trunks of the former. At one place, $8 \mathrm{~m}$ from the shore, we inserted a $1.8 \mathrm{~m}$ probe its full length into the peat, encountering increasing resistance but not touching bottom. At another place, two metres from the shore, the probe descended one metre into the peat. In other places, the probe encountered large rocks like those that occur plentifully all along the base of the slope, as well as some softer objects that possibly were previous generations of trunks and stumps, all less than a metre below the surface.

Along the northeastern and northern shores of the lake beyond the wetland, many more large Betula papyrifera stumps were exposed by the drop in water level. 
They likely were the remains of the trees shown on the air photos lining the lake shore in the 1920s. Their positions indicate that the drop in 2003 brought the water level back almost to the low level of the 1920s.

As the summer progressed, vegetation developed quickly on the exposed peat. Two different but overlapping communities could be distinguished. A Sparganium-Sagittaria community was established closer to the lake, around and in shallow ponds where the water table was close to or at the surface (shallow pool zone). A community of moist to wet habitat, mostly weedy species formed on the broad band of saturated to moist peat between the previous zone and the upland shore (upper shore zone). (The Appendix lists the species that were recorded from each zone.) During the summer, the islands stranded in previous years on the north and south shores continued to dry out and disintegrate.

In 2004 the water level continued at the 2003 level. The plant communities of the previous year became increasingly established. Only one new species was found, a few plants of Aster lanceolatus Willd. in the upper shore zone. Several additional species that were present in the upper shore zone in 2003 had invaded the northern beached peat island: Euphrasia stricta, Bidens connata, Euthamia graminifolia, Solidago canadensis and Dulichium arundinaceum. The base of this island was in contact with the lake water in the late summer and fall. All of the peat islands have disintegrated to the extent that they seem unlikely to survive for more than a few years. The Beavers built yet another lodge, this one over a peat island near the north end of the former fen. Thus, since 1978, Beavers have built five lodges around the lake, four on the former fen and one in the northwestern corner of the lake (at a different location from that shown on the 1966 and 1971 air photos). In 2004 two of the lodges showed evidence of occupation, the one that was built this year and the one across the lake. The seasonal variation in water level during these two years of relatively normal rainfall and temperatures was in the range of $20 \mathrm{~cm}$, except for the record $14 \mathrm{~cm}$ rainfall from the remnant of Hurricane Frances, which briefly raised the water level by about $24 \mathrm{~cm}$ in September 2004.

\section{Discussion}

The level of the water in Black Lake appears to have been the most important factor in determining the nature of the wetland over the past century and a quarter, and presumably for much longer. In the 1920s the water level was relatively low. Judging by the presence of large trees along the shores and in the wetland, we deduce that it had been low for many decades. There was an episode of fluctuating higher water levels in the 1930s, 1940 s, and early 1950 s followed by a return to the former low level. This level was maintained until the end of the 1970 s. From the early 1980 s to 2003 there was a period of even higher water than before. This second rise in lake level was the work of Beavers, and it may be that Beavers contributed to the high water of the 1930s and 1940s, perhaps in conjunction with other natural causes. The later increase in water level was of the order of one metre and we estimate that the earlier increase at its peak was about half that. In 2003 the water level dropped almost to the low level of the 1920s.

Until the late 1940s, water levels remained low enough to support a peatland consisting of a lacustrine swamp with a band of open fen along the lake edge. The trees of the swamp appear in air photos to have been a moderate size in 1948. This size correlates with the $30-45 \mathrm{~cm}$ basal diameter stumps and corresponding trunks of Betula papyrifera that were exposed when the water receded in 2003. The few Pinus strobus and Thuja occidentalis stumps and trunks may be from the same generation of trees as the $B$. papyrifera. The trees that grew in the central part of the wetland show evidence of stunted growth, reflecting the poor growing conditions of the peatland. Betula papyrifera is a common colonizer of open sites on a variety of soils, including wetlands (personal observation), and is often found in pure stands (Farrar 1995). Thus it is likely that the presence of $B$. papyrifera trees of an even age is evidence of a previous disturbance in the late nineteenth century.

By 1951 the water evidently had risen high enough and lasted long enough to kill the trees in the swamp, but appears not to have seriously affected the open fen. Over the next decade the water receded to the former low level, perhaps because a newly built Beaver dam was left unattended and consequently deteriorated after the Beavers were trapped out or had moved on. By the 1960s, a new generation of Betula papyrifera and Alnus incana began to grow in the area of the former swamp, which by then had developed into a Sphagnum lawn. The open fen was a semi-floating Chamaedaphne shrub fringe between the Sphagnum lawn and the lake. The peatland supported more than 18 species of vascular plants in 12 families. Most studies of the impact of higher water levels on peatlands have been made on bogs and have some parallels to the present work. For example, Schwintzer (1979) has described how moderately raised water levels killed the trees in a treed bog in Michigan. The resultant increased light on the bog mat enhanced the development of Sphagnum species and Chamaedaphne.

Beavers were present in the lake in the 1960s and the impact of their increasingly high dam at the outlet of the lake began to affect the fen in the late 1970s. Because the Sphagnum lawn was grounded, rising water killed all of the vegetation, including the trees, within a few years. The area of the drowned fen was replaced by a Nuphar-Sparganium shallow water wetland that lasted until the spring of 2003. The shallow water wetland essentially was an extension over the peat substrate of the aquatic zone already present around the other margins of the lake (Aiken and Gillett 1974).

The original shrub fringe stayed afloat as the water rose but fragmented into a line of islands, which have disintegrated over time. Some of the Chamaedaphne 
shrubs died and Carex lasiocarpa became the co-dominant cover, perhaps because there was a change in the water regime. The composition of the vegetation community on the islands also changed to form a gradient from south to north, the southern islands supporting a restricted number of species, while the composition of the northern islands resembled that of the previous Sphagnum lawn (see Appendix). The occurrence of this gradient perhaps can be correlated with the amount of sunlight available through the growing season, the southern islands being increasingly more in the shadow of the slope above them. For instance, from 1980 until the present, the heliophilous orchid Pogonia ophioglossoides has been present predominantly on the northern islands. Assuming continuity of fen habitat from 1878 to the present, this is the longest recorded colony of orchids in the Ottawa District (Reddoch and Reddoch 1997).

When the water level dropped a metre in the spring of 2003 as a result of the Beaver dam giving way, the peat generated over the years or centuries by fen vegetation lay exposed. For the first time, emergent and other plants in the seed bank were given the opportunity to germinate. The vegetation that became established on the peat in the first summer consisted of essentially two zones: a Sparganium-Sagittaria community in the saturated peat and shallow pools closer to the lake, and an upper shore zone of moist to wet habitat species around the inland edge. A total of 39 species in 21 families made up the vegetation communities in the two zones. Four of the 30 species (13\%) in the upper shore zone were aliens (see Appendix). That there is spacial separation of species in relation to water level is well known (see, e.g., Odland and del Moral 2002). The species in the two zones are characteristic of these habitats in the Ottawa area. Most of the species in the upper shore zone were also present on the adjacent eastern shore of Black Lake. They included only two of the five most abundant species listed by Le Page and Keddy (1998) as buried seeds in nearby Beaver ponds in Gatineau Park. Of the total of 37 species that LePage and Keddy (1998) discovered in Beaver pond sediments in the park, only 11 species in all were present in the upper shore zone at Black Lake. The shallow pool zone included about eight of the 16 aquatic species that were identified in 1971 by Aitken and Gillett (1974) from the margins of the lake.

As Crum (1988) has pointed out, it is difficult to estimate the rate of peat accumulation. He suggested that peatlands in the area of the upper Great Lakes can take 100 to 900 years to produce $30 \mathrm{~cm}$ of peat. Using these numbers, one can deduce that the depth of the peat in the Black Lake wetland, which is at least $1.8 \mathrm{~m}$ deep, may have taken between 600 and several thousand years to develop. An accumulation rate consistent with Crum was obtained from a core taken in the Mer Bleue peatland in the Ottawa Valley $30 \mathrm{~km}$ to the southeast (Camfield 1969). Unlike the Mer Bleue, the Gatineau Park area where Black Lake is located was not flooded by the Champlain Sea but has been open since the Wisconsin glaciation retreated about 12000 before present (Romanelli 1975).

Mott and Farley-Gill (1981) state that the almost unchanged forest composition in the Gatineau Park area over the past 3200 years indicates that there have been only minor variations in the climate during that time. The only major changes in the forest composition have occurred since logging began in the area about 175 years ago. It is not known what impact, if any, logging has had on the Black Lake wetland nor whether the trees in the wetland have ever been logged. A few of the larger stumps have flat tops, but the condition of the wood in all of them precludes any definite conclusions. It is possible that any dead trunks still standing in the mid-1960s were cut down at the same time that the adjacent eastern slope was cleared of undergrowth, presumably to improve the view from the newly built parking lot beyond the eastern slope.

It is recognized that Beaver flooding in certain circumstances can increase species richness and landscape diversity. In a forested region such as the Adirondacks, New York, ecosystem engineering by Beavers has introduced wetlands into the landscape (Wright et al. 2002). On the other hand, at Black Lake, Beaver flooding destroyed the shore fen that had made a unique contribution to the biological diversity of Gatineau Park (Gillett and Catling 1983). The fen has been replaced, over the short term at least, by plant species already well represented in the lake's aquatic and shoreline flora. Fens are the product of centuries of development and cannot quickly redevelop.

The provincially extremely rare Blanding's Turtle was present in the shallow water wetland phase at Black Lake in 1994. Since this elusive turtle is known to occur in (and move between) various types of wetlands, including peatlands (Bider and Matte 1996; Cook 1981, 1984; McMurray 1984*; Desroches and Rodrigue 2004), it is not known how the changes in Black Lake over the past several decades have affected its suitability for this species. This turtle is known in the province only from a few reports in southwestern Quebec (McMurray 1984*; Bider and Matte 1996; Desroches and Rodrigue 2004).

Preserving the fen at Black Lake would have required maintaining historic low water levels. Every few decades a short period of higher water (about half a metre higher) would have been required to kill the trees. If the preservation of existing natural communities in Gatineau Park had been a criterion when the objectives for managing Beavers were drawn up, much more careful attention would have had to be given to the impact of changing water levels on these communities.

\section{Acknowledgments}

We are grateful to Francis R. Cook, Researcher Emeritus, Canadian Museum of Nature, for information and valuable comments on the Blanding's Turtle in Quebec, as well as confirming our identification of the 
Blanding's Turtle that we photographed at Black Lake; to Stephen J. Darbyshire, Biologist, Agriculture and Agri-food Canada, for identifying the grasses; to Robert R. Ireland, former Curator, Canadian Museum of Nature, for identifying the 1978 mosses; and to Donna Naughton, Research Assistant, Research Services, Canadian Museum of Nature, for background papers on Beavers. We thank the following staff of the National Capital Commission, Gatineau Park: Michel Viens, Senior Manager, Natural Resources and Land Development, for a permit to conduct this research in Gatineau Park, and Isabelle Beaudoin-Roy, Biologist, for providing background information and reports, and, in addition, Michel Leclair, contractor for Beaver management in the Park, for information on Beaver activities and management strategies.

\section{Documents Cited (marked * in text)}

Éco-recherches Inc. 1983. Inventaires écologiques de lacs du Parc de la Gatineau 1982. Commission de la capitale nationale, Ottawa, Ontario. 17 pages + annexes.

Environment Canada. 2004. National Climate Archive. Environment Canada, Ottawa, Ontario. Website (www. climate.weatheroffice.ec.gc.ca). Accessed October 2004.

McMurray, I. 1984. A herpetofaunal study of Gatineau Park. Unpublished report to Gatineau Park, National Capital Commission. Volumes 1-5.

Muir-Hotaling, N. E. c. 2001. New York State fens. College of Environmental Science and Forestry, State University of New York, Syracuse, NY. Website (www.esf.edu/resorg/ rooseveltwildlife/Research/Fen/Fen.htm). Accessed October 2004.

National Capital Commission. 2004. Gatineau Park. National Capital Commission, Ottawa, Ontario Website (www.canadascapital.gc.ca/gatineau/nature/index_e.asp). Accessed October 2004.

Société de la faune et des parcs. 2004. Espèces fauniques menacées ou vulnérable au Québec/Tortue mouchetée. Société de la faune et des parcs du Québec, Québec. (www. fapaq.gouv.qc.ca). Accessed October 2004.

\section{Literature Cited}

Aiken, S., and J. M. Gillett. 1974. The distribution of aquatic plants in selected lakes in Gatineau Park, Quebec. Canadian Field-Naturalist 88: 437-448.

Banfield, A. W. F. 1974. The mammals of Canada. University of Toronto Press, Toronto, Ontario. 438 pages.

Bider, J. R., and S. Matte. 1996. The atlas of amphibians and reptiles of Québec. St. Lawrence Valley Natural History Society, Sainte-Anne-de-Bellevue, and Ministère de l'Environnement et de la Faune, Direction de la faune et des habitats, Québec. 106 pages.

Camfield, M. 1969. Pollen record at the Mer Bleue. Canadian Field-Naturalist 83: 7-13.

Cook, F. R. 1981. Amphibians and reptiles of the Ottawa District. Trail \& Landscape 15: 75-109.

Cook, F. R. 1984. Introduction to Canadian amphibians and reptiles. National Museum of Natural Sciences, National Museums of Canada, Ottawa, Ontario. 200 pages.

Crowe, R. B. 1984. The climate of Ottawa-Hull. Climatological Studies Number 35, The Climate of Canadian Cities Number 1. Environment Canada, Ottawa, Ontario. 42 pages.
Crum, H. 1988. A focus on peatlands and peat mosses. University of Michigan Press, Ann Arbor, Michigan. 306 pages.

Damman, A. W. H., and T. W. French. 1987. The ecology of peat bogs of the glaciated Northeastern United States: a community profile. U.S. Fish and Wildlife Service, Biological Report 85(7.16). 100 pages.

Desroches, J.-F., and D. Rodrigue. 2004. Amphibiens et reptiles du Québec et des Maritimes. Éditions Michel Quintin.

Dore, W. G., and J. McNeill. 1980. Grasses of Ontario. Monograph 26. Agriculture Canada, Ottawa, Ontario. 566 pages.

Farrar, J. L. 1995. Trees in Canada. Fitzhenry \& Whiteside Ltd., Markham, and Canadian Forestry Service, Natural Resources Canada, Ottawa, Ontario. 502 pages.

Fletcher, J. 1889a. Flora Ottawaensis. Ottawa Naturalist 2: 40.

Fletcher, J. 1889b. Flora Ottawaensis. Ottawa Naturalist 3: 62 [incorrectly paged 121].

Fletcher, J. 1893. Flora Ottawaensis. Ottawa Naturalist 7: 84-89.

Gillett, J. M., and P. M. Catling. 1983. History, geomorphology and vegetation of Gatineau Park. In The Arthropods of Gatineau Park. Edited by J.D. Lafontaine et al. Agriculture Canada Technical Bulletin. Reprinted in Trail \& Landscape 28: 129-138 (1994).

Gillett, J. M., and D. J. White. 1978. Checklist of vascular plants of the Ottawa-Hull Region, Canada. National Museum of Natural Sciences, National Museum of Canada, Ottawa, Ontario. 155 pages.

Hoadley, R. B. 1990. Identifying wood. Taunton Press, Newtown, Connecticut. 224 pages.

Hogarth, D. D. 1962. A guide to the geology of the Gatineau Lièvre district. Canadian Field-Naturalist 76: 1-55.

Hogarth, D. D. 1970. Geology of the southern part of Gatineau Park, National Capital Region. Paper 70-20 and Map 7-1970. Geological Survey of Canada, Ottawa, Ontario.

Ingle-Sidorowicz, H. M. 1982. Beaver increase in Ontario. Result of changing environment. Mammalia 46: 167-175.

Le Page, C., and P. A. Keddy. 1998. Reserves of buried seeds in Beaver ponds. Wetlands (Wilmington) 18: 242-248.

Lopoukhine, N. 1974. The forests and associated vegetation of Gatineau Park, Quebec. Information Report FMR-X-58. Forest Management Institute, Canadian Forestry Service, Ottawa, Ontario. 51 pages + appendices.

Mitchell, C. C., and W. A. Niering. 1993. Vegetation change in a topogenic bog following beaver flooding. Bulletin of the Torrey Botanical Club 120: 136-147.

Mott, R. J., and L. D. Farley-Gill. 1981. Two late quaternary pollen profiles from Gatineau Park, Quebec. Paper 80-31. Geological Survey of Canada, Ottawa, Ontario. 10 pages.

National Wetlands Working Group. 1997. The Canadian Wetland Classification System. Second edition. Wetlands Research Centre, University of Waterloo, Waterloo, Ontario. 68 pages.

Newmaster, S. G., A. Lehela, P. W. C. Uhlig, S. McMurray, and M. J. Oldham. 1998. Ontario plant list. Ontario Ministry of Natural Resources, Ontario Forest Research Institute, Sault Ste. Marie, Ontario, Forest Research Information Paper No. 123. 550 pages + appendices.

Odland, A., and R. del Moral. 2002. Thirteen years of wetland vegetation succession following a permanent drawdown, Myrkdalen Lake, Norway. Plant Ecology 162: 185-198.

Panshin, A. J., and C. de Zeeuw. 1980. Textbook of wood technology, Fourth edition. McGraw-Hill Book Co., Toronto, Ontario. 722 pages. 
Peterson, R. L. 1966. The mammals of Eastern Canada. Oxford University Press, Toronto, Ontario. 465 pages.

Rebertus, A. J. 1986. Bogs as Beaver habitat in north-central Minnesota. American Midland Naturalist 116: 240-245.

Reddoch, J. [M.] 1979. Calcareous fens in the Ottawa District. Trail \& Landscape 13: 16-27.

Reddoch, J. M. 1984. White Lake Fen. Trail \& Landscape 18: 134-141.

Reddoch, J. M. 1989. Fens of the Ottawa District update. Trail \& Landscape 23: 111-115.

Reddoch, J. M., and A. H. Reddoch. 1987. The three "pink" peatland orchids. Trail \& Landscape 21: 196-201.

Reddoch, J. M., and A. H. Reddoch. 1997. The orchids in the Ottawa District: floristics, phytogeography, population studies and historical review. Canadian Field-Naturalist 111: $1-185$.

Romanelli, R. 1975. The Champlain Sea episode in the Gatineau River Valley and Ottawa area. Canadian FieldNaturalist 89: 356-360.
Rowe, J. S. 1972. Forest regions of Canada. Canadian Forestry Service, Dept. of the Environment, Ottawa, Ontario. 172 pages and map.

St. George, I. 2002. July in Gatineau Park. New Zealand Native Orchid Group Journal 84: 7-11.

Schwintzer, C. R. 1979. Vegetation changes following a water level rise and tree mortality in a Michigan bog. Michigan Botanist 18: 91-98.

Schwintzer, C. R., and G. Williams. 1974. Vegetation changes in a small Michigan bog from 1917 to 1972 . American Midland Naturalist 92: 447-459.

Wright, J. P., C. G. Jones, and A. S. Flecker. 2002. An ecosystem engineer, the beaver, increases species richness at the landscape scale. Oecologia 132: 96-101.

Received 28 October 2004

Accepted 17 August 2005

\section{APPENDIX: VASCULAR PLANTS AND MOSSES OF THE BLACK LAKE WETLAND 2002-2003}

Nomenclature (except for grasses) and arrangement follow Newmaster et al. (1998); nomenclature for grasses follows Dore and McNeill (1980). The abundance of each species is ranked on a subjective scale from rare through occasional, frequent and common. An asterisk (*) indicates an alien species (Gillett and White 1978).

\section{Partially Floating and Recently Beached Islands: 2002-2003}

\author{
BRYOPHYTA (Mosses) \\ Sphagnum magellanicum Brid. — common \\ Sphagnum teres (Schimp.) Ångstr. in Hartm. — occasional \\ Campylium sp.- rare \\ POLYPODIOPHYTA (Ferns) \\ THELYPTERIDACEAE \\ Thelypteris palustris Schott — frequent \\ MAGNOLIOPHYTA (Flowering Plants) \\ Magnoliopsida (Dicotyledons) \\ BETULACEAE \\ Alnus incana (L.) Moench ssp. rugosa (Du Roi) Clausen - \\ rare, one seedling \\ GUTTIFERAE \\ Triadenum virginicum (L.) Raf. - occasional \\ DROSERACEAE \\ Drosera rotundifolia L. - rare \\ VIOLACEAE \\ Viola macloskeyi F. E. Lloyd ssp. pallens (Banks ex DC.) \\ M. Baker - rare
}

ERICACEAE

Chamaedaphne calyculata (L.) Moench - common

PRIMULACEAE

Lysimachia thyrsiflora L. — rare

LAMIACEAE

Lycopus uniflorus Michx. — rare

ASTERACEAE

Bidens sp. - rare

Eupatorium perfoliatum L. - rare

LILIOPSIDA (Monocotyledons)

CYPERACEAE

Carex lasiocarpa Ehrh. - occasional to common

Carex pseudo-cyperus L. - rare

TYPHACEAE

Typha latifolia L. - rare

IRIDACEAE

Iris versicolor L. - occasional

ORCHIDACEAE

Pogonia ophioglossoides (L.) Juss. — occasional in 2002; rare in 2003 


\section{Peaty Shore 2003}

\section{Magnoliophyta (Flowering Plants)}

Magnoliopsida (Dicotyledons)

NYMPHAEACEAE

Nuphar variegata Durand in Clinton - occasional, shallow pool zone; remnant, non-flowering plants

POLYGONACEAE

*Polygonum persicaria L. — rare, upper shore zone

GUTTIFERAE

Hypericum mutilum L. - frequent, upper shore zone

Triadenum virginicum (L.) Raf. — occasional, upper shore zone

\section{VIOLACEAE}

Viola macloskeyi F. E. Lloyd ssp. pallens (Banks ex DC.)

M. Baker - occasional, upper shore zone

ROSACEAE

Fragaria virginiana Miller - occasional, upper shore zone Potentilla norvegica L. — occasional, upper shore zone

*Potentilla recta L. — rare, upper shore zone

ONAGRACEAE

Epilobium ciliatum Raf. — rare, upper shore zone

Epilobium coloratum Biehler — rare, upper shore zone

BALSAMINACEAE

Impatiens capensis Meerb. — frequent, upper shore zone

\section{APIACEAE}

Cicuta bulbifera L. - rare, upper shore zone

Hydrocotyle americana L. - rare, upper shore zone

LAMIACEAE

Lycopus uniflorus Michx. - occasional, upper shore zone

Scutellaria galericulata L. - rare, upper shore zone; common on unused beaver lodge

\section{PLANTAGINACEAE}

*Plantago major L. — occasional, upper shore zone

SCROPHULARIACEAE

*Euphrasia stricta D. Wolff ex Lehm. - occasional, upper shore zone

\section{CAMPANULACEAE}

Lobelia inflata L. - occasional, upper shore zone

RUBIACEAE

Galium tinctorium L. — occasional, upper shore zone

\section{ASTERACEAE}

Bidens cernua L. - frequent, upper shore zone

Bidens connata Muhl. ex Willd. - occasional, upper shore zone

Erigeron philadelphicus L. — rare, upper shore zone

Eupatorium maculatum L. — occasional, upper shore zone

Eupatorium perfoliatum L. - occasional, upper shore zone

Euthamia graminifolia (L.) Nutt.-occasional, upper shore zone

Solidago canadensis L. — rare, upper shore zone

LILIOPSIDA (Monocotyledons)

ALISMATACEAE

Sagittaria latifolia Willd. — frequent, shallow pool zone

POTOMAGETONACEAE

Potamogeton epihydrus Raf. — rare, shallow pool zone

JUNCACEAE

Juncus brevicaudatus (Engelm.) Fern. — frequent, shallow pool zone

Juncus canadensis J. Gay ex Laharpe — frequent, shallow pool zone

\section{CYPERACEAE}

Carex bebbii (L. H. Bailey) Olney ex Fern. — frequent, upper shore zone

Carex pseudo-cyperus L. - rare, upper shore zone

Dulichium arundinaceum (L.) Britton — frequent, shallow pool zone

Eleocharis obtusa (Willd.) Schult. — rare, shallow pool zone

Eleocharis sp.

Scirpus cyperinus (L.) Kunth — rare, upper shore zone

POACEAE

Agrostis scabra Willd. — frequent, upper shore zone

Torreyochloa pallida (Torr.) Church var. fernaldii (A. S. Hitchc.) Dore - rare?, upper shore zone

\section{SPARGANIACEAE}

Sparganium americanum Nutt. — common, shallow pool zone

TYPHACEAE

Typha latifolia L. — occasional, shallow pool zone, lake edge

IRIDACEAE

Iris versicolor L. — occasional, upper shore zone 